\title{
Variability of Academic Adjustment of First Years among Public Kenyan Universities
}

\author{
Osoro Gladys Nyaboke, Dr. Callen Nyamwange, PhD \\ Senior Lecturer \\ Educational Counselling Psychology \\ Education and Human Resource Development \\ Kisii University
}

Abstract:- Adjustment to University was defined in terms of academic; the study endeavoured to determine the influence of orientation programme on first-year students' academic adjustment in public universities in Kenya; Mixed methods research approach was used. The study utilized a descriptive survey design. Twostage cluster sampling, simple random sampling, and purposeful sampling techniques were employed to obtain 479 respondents from the target population of 71,285. The study was conducted in nine public universities in Kenya between January and April 2019. Data was collected using three research instruments: a questionnaire, focused group discussions, and in-depth interview schedule. The tools were validated by two experts from Kisii University, while reliability was determined through the test-re-test method in a pilot study for a first-year student questionnaire. Both qualitative and quantitative techniques (Content Analysis, Means and Standard Deviations, Factor Analysis, Analysis of Variance (ANOVA), and Post-hoc t-tests) were utilized to analyze data with the aid of the computer-based Statistical Package for Social Sciences (SPSS) version 22.0. Research hypotheses were tested at $\alpha \leq 0.05$ level. Findings indicatethat the duration of the orientation programme, activities and how they are carried out together with the location and size of the universities in terms of the student population and organizational structure do influence the level of adjustment realized by first-year students. Besides, academic adjustment was higher in old universities than in new universities. This will inform the design and implementation of diverse guidelines and programmes suitable to meet first-year students' requirements.Further, results will enlighten first-year students to recognize their situation and be encouraged to seek more timely assistance and services. The study recommends that when developing orientation programmes, universities need to identify specific desired outcomes in all areas of first year students' academic adjustment and create programmes that align with those unique demands.Universities may consider adopting an extended orientation programme by integrating orientation materials into the curriculum during the first semester.

Keywords:- Adjustment, academic, programmes, outcomes, first-year and students.

\author{
Dr. Enock Obuba, PhD \\ Lecturer \\ Curriculum Instruction and Media \\ Education and Human Resource Development \\ Kisii University
}

\section{INTRODUCTION}

Academic adjustments denote student's capacity to attain balance and satisfaction in tackling academic matters effectively(Al-khatib, Awamleh, and Samawi, 2012). For students to adjust academically, Mohamed (2012) supposed that they need higher intellectual, critical thinking, and academic writing. WhereasSalami (2011) and Mudhovizi (2012) suggest that students ought to embrace new methods of instruction: and adjust to a shift from subjects at secondary to discipline-based at the University (Abdullah et al., 2009). Accordingly, Brinkworth, Mccann, Matthews, and Nordstom (2009) observe that first-year students are expected to adjust to the new learning environment by adopting self-directed learning habits. Unfortunately, according to Bok (2010), past learning experiences in secondary schools do not prepare students sufficiently for these demands. Additionally, students face the challenge of congestion in classes, libraries, and laboratories due to inadequate teaching and learning infrastructure (Gudo\&Olel, 2011; Otieno, 2013). As such, students in need of assistance often undergo pains and struggles unnecessarily.

\section{$>$ Statement of the Problem}

The hope of the government, parents, and university administrators is that students who join university will successfully engage and acquire knowledge, skills, and abilities and complete studies within the stipulated period and be ushered into the word of work. However, this is not often the case, as some students encounter difficulties in developing self-regulated learning habits, handling assignments, and connecting with staff and senior students. Other students develop inferior study habits; engage in examination malpractices, course deferment, poor financial management skills, and reduced time management. As a result of these challenges, some students end up dropping out while in the first year, others commit suicide while others end up various forms of addictions.

Orientation programme has been considered as one of the major intervention strategies to help first-years assimilate to the academic life of the new university environment. Through the programme, students are facilitated to handle the academic challenges they face when they join University. Even though it is evident that first-year students do benefit as a result of participation in the different forms of orientation programmes, their effectiveness remains questionable. A study by Emmanuel 
and Ovie (2015) for instance established that due to lack of a well-organized orientation programme whose activities don't align well with the current needs of transitioning students among other factors, students encounter academic adjustment challenges as they transit to the institution. Therefore, this study sought to determine the influence of orientation programme in adjustment of first-year students in public universities in Kenya.

\section{Research Objective}

The study's objective was to determine the variability of academic adjustment of first years in public Kenyan universities.

\section{LITERATURE REVIEW}

According to Budgen Main, Callcott, and Hamlett (2014), academic adjustment refers to motivation to learn and complete academic requirements, sense of purposefulness, and satisfaction with the academic environment.Academic adjustment to University is critical for academic success. Mohamed (2012) argues that adverse educational change correlates with poor academic performance, low graduation rates, and reduced prosperity. Research has established a significant positive relationship between academic adjustment and academic achievement, indicating that students who are well adjusted academically achieve higher marks (Clark \& Hall, 2010; Tinto, 2012). Nevertheless, Hassel and Ridout (2018) reported that firstyear students experience academic struggles as they enter University. This has been attributed to research outcomes confirming that many students arrive at University with unrealistic expectations that are not addressed on time (Crisp, Palmer, Turnbull, Netelbeck, \& Ward, 2009; Murtagh, 2010; Kandinko\&Mawer, 2013).

In addressing academic expectations, Briggs et al. (2012) point out that failure to get proper orientation concerning academic expectations during the transition period may lead to a mismatch between expectations and the reality about university life. Correspondingly, Williamson, Laybourn, Deane, and Tait, (2011) argue that the harmony, or discrepancy, between student and staff expectations, is significant because it can affect not only students' academic performance but also their social and emotional wellbeing.

The suggestion by Mudhovizi (2012) calls for a paradigm shift in the lives of transiting students. Nevertheless, Wasylkiw (2016) argues that in trying to meet these demands, students may doubt their ability because, for many, independent thinking is a new experience as they are used to relying on their teachers as the supreme authority to remind, guide and structure learning. Besides, students encounter bigger classrooms, several teachers, and a more demanding workload. Students' doubt of their ability to be successful at the university level may increase their stress level and lower their learning outcomes (Leese, 2010).

Various studies reveal that pre-university experiences of first-year students on matters academic markedly differ with the real experiences at the University. For instance, Salami's (2011) survey on psychosocial predictors of adjustment among first Year College of education in Kampala International University found learning packages and teaching methodologies different from secondary, reading assignments, and examinations. These cover a broader amount of materials with lectures expecting students to do more outside the classroom. Similarly, Hassel and Ridout's (2018) study on an investigation of first-year students' and lecturers' expectations of university education, established that 39percent of students struggled to keep up with the workload while over 30 percent encountered challenges in developing an independent learning style.

Equally, Meuleman et al., (2015) study on 'Some people might say I'm thriving but ... ': non-traditional students' experiences of University indicate that students faced challenges such as not receiving enough assistance from tutors and lecturers as expected, increased responsibility for learning, high expectations, adjustment to different grading systems, and general difficulty of assignments. For example, a report by Crisp et al. (2009) indicates that students expected lecturers to provide detailed feedback on drafts of their work and that staff would be able to return assessed work within a week. Nevertheless, usually, this is not the norm. Despite the evidence of corresponding staff/student expectations, there are still cases of discrepancies between the students' expectations of the role of staff and university life's reality (Hassel and Ridout 2018). For this reason, Brinkworth et al. (2009) argue that lack of clarification, feedback, or personal attention further promotes a sense of anxiety among firstyear students because university experiences are significantly different from secondary school experiences.

Further, academic adjustment has been found challenging for some first-year students because preuniversity educational experience does not adequately prepare them for study at the University (Bok 2010). As a result, students find the discourses of academic disciplines in University confusing and mysterious (Rice, 2009). The students demonstrated a liking for small tutorial-style classes that present more excellent opportunities for faceto-face interactions with teaching staff. Regrettably, the rapid expansion of the higher education sector in Kenya has seen a movement toward greater reliance on large lecturestyle classes to deliver course material rather than small group teaching (Gudo\&Olel, 2011; Otieno, 2013), especially during the first year. 


\section{RESEARCH METHODOLOGY}

\section{$>$ Research Design}

Research design is the overall strategy used to integrate the different components of the study coherently and logically to address the research problem (Trochim, 2020) effectively. The design establishes the outline for the collection, measurement, and analysis of data. This study utilized a descriptive-survey research design. Gall, Gall, and Borg (2007) explain that descriptive-survey research design is a type of research that uses surveys to gather data that describes a population, situation, or phenomenon that is being studied. Descriptive research accurately and systematically escribe a population, situation, or phenomenon and can use a wide variety of quantitative and qualitative methods to investigate one or more variables. In this study, data were collected using surveys, in-depth interviews, and focused group discussions. Descriptivesurvey research design was considered appropriate for this study because it allowed the use of a survey to gather large volumes of data from a large population within a short period. Besides, the design allowed the researcher to use both qualitative and quantitative approaches to collect data without manipulating any of the variables.

The use of mixed methods approaches to collect data allowed the researcher to collect diverse types of data that captured different dimensions on the influence of orientation programme on adjustment of first-year students in public universities in Kenya thus, providing a complete understanding of the research problem.It is in line with the assertion that integrating quantitative and qualitative data provides a comprehensive analysis of the research problem rather than quantitative or qualitative data alone(Creswell 2014). In this study, the researcher administered questionnaires to first-year students that yielded Quantitative data. In contrast, qualitative data was drawn from Focus Group Discussions (FGDs) conducted among student leaders and peer counselors, and in-depth interviews schedules conducted among student counselors and deans of students. Burke and Larry (2012) argue that the utilization of qualitative and quantitative data neutralizes the weaknesses of each form of data and, therefore, produces results that are superior to the ones produced by either qualitative or quantitative research alone.

\section{The population of the study}

According to Ary, Jacobs, Sorensen Irvine, and Walker (2019), a population is a group of elements that possess the characteristics sought that may lead to drawing inferences. The study's target population was first-year, second-semester students, student leaders, peer counselors, student counselors, and deans of students in Kenyan public universities. The first-year students formed the first category of respondents, and student leaders, peer counselors, student counselors, and deans of students formed the second category.
Target population of the First category of respondents

According to the Kenya Universities and Colleges Central Placement Services (KUCCPS) (2017), 88,457 Kenya Certificate of Secondary Education (KCSE) candidates were placed in public and private universities; 71,089 students in public universities while 17,368 in private universities. However, statistics from respective universities Academic Registrars' offices indicate 69,115 students reported; 39,233 males and 29,882 females. Table 3.2 below shows how the target population was distributed. First-year second-semester students were considered suitable because the adjustment is a process. Having stayed in the University for one semester after having gone through orientation in the first semester, they were presumed to have gone through the adjustment process and become more aware of the services available and operations of the University.

\section{$>$ The target population of the second category of respondents}

The target population for other university respondents was 2170is comprised 217 student leaders, 1860 peer counselors, 62 student counselors and 31 deans of students.

\begin{tabular}{|c|c|c|}
\hline Respondent & population & Sample \\
\hline Student leaders & 217 & 27 \\
\hline Peer counselors & 1860 & 36 \\
\hline Student counselors & 62 & 9 \\
\hline Deans of students & 31 & 9 \\
\hline Total & $\mathbf{2 1 7 0}$ & $\mathbf{8 1}$ \\
\hline
\end{tabular}

Table 1:- Distribution of the second category of the target population

Source: Researcher (2020)

The additional 81 respondents were considered vital as they encountered first-year students as they report to the University during orientation and are responsible for handling student concerns, and make decisions on the campus-related issues presented to them.

\section{> Sample and the Sampling Techniques}

A sample is representative of the total population under study. Simultaneously, sampling is a process used in statistical analysis in which a predetermined number of observations are taken from a large population (Cohen, Manion, \& Morrison, 2007). The methodology used for sampling depends on the type of analysis being performed. The researcher employed two-stage cluster sampling, simple random sampling, and purposeful sampling techniques to obtain a sample. Cluster sampling is a sampling method in which the entire population of the study is divided into externally homogeneous but internally heterogeneous; groups called clusters (Mugenda \& Mugenda, 2013). The researcher clustered the 31chartered public universities into old and new universities. The old universities were considered those that had been in existence for more than ten years; they were seven (7) while the new universities were those chartered from 2010 to date and numbered twenty-four (24). Mugenda \& Mugenda (2013) stated that $30 \%$ of the population makes an excellent representation to generalize the findings. The 
researcher sampled $9(30 \%)$ out of 31 universities to participate in the study.

Further, these universities were clustered into urban and rural. That is, those located in major cities and those located in a more or less rural setting. Two old universities and seven new universities were sampled using a proportionate sampling technique.

Then after identifying the clusters, a simple random sampling technique was applied to obtained two (2) old universities, one from an urban setting and another from a rural setting. Likewise, the researcher selected seven (7) new universities, three (3) from an urban setting, and four (4) from rural settings using a simple random sampling technique.

Using Slovin's formula, a sample size of 398 firstyear university students from 69,115 students was sampled. Also, a purposive sampling technique was used to sample 81 second category of respondents from 2170 respondents comprising 27 student leaders, three (3) from each University (those who held key positions in the student leadership such as; Chairperson, Secretary-General, and Academic Secretary, 36 peer counselors, four (4) from each University, nine (9) Student Counsellors one (1) from each University, and nine (9) Deans of Students, one (1) from each University were interviewed. Thus, the total number of respondents, including students, was 479 .

\section{Sample size}

The sample size is the number of items selected from a population to constitute a sample. This sample size was selected at a 95\% confidence level and margin error/precision level of 0.05 . Slovin's formula shown below was used in determining the sample size that was required. This sample size was sufficient to generalize findings and draw conclusions for the study.

$$
\begin{gathered}
\mathrm{n}=\frac{N}{1+N e^{2}} \\
\text { Where: }
\end{gathered}
$$

$\mathrm{n}=$ Sample size required

$\mathrm{N}=$ Target population

$\mathrm{e}=$ Margin error

$1=$ Constant value

$\mathrm{n}=69,115 / 1+69,115(0.05)^{2}$

$\mathrm{n}=69115 / 173.788$

$=398$

A sample of 398 students was used. Each University sampled, the single sample size was obtained using Probability Proportionate Sample (PPS) formulae. The table below shows the sample distribution of the students:

$\mathrm{S}=\frac{n N i}{N}$

Where:

$\mathrm{n}=$ sample size

$\mathrm{Ni}=$ cluster population, and

$\mathrm{N}=$ population

\begin{tabular}{|c|c|c|}
\hline University Category & First-year Student sample & Population \\
\hline Old Urban & 111 & 19275 \\
\hline Old Rural & 86 & 14934 \\
\hline New Urban & 103 & 17887 \\
\hline New Rural & 98 & 17019 \\
\hline Total & $\mathbf{3 9 8}$ & $\mathbf{6 9 1 1 5}$ \\
\hline
\end{tabular}

Table 2:- Population and sample size

It is clear that using Probability Proportionate Sample (PPS) formulae, 19275 students from old urban, 14934 from old rural, 17887 students from new urban, and 17019 students from new rural universities were obtained.

\begin{tabular}{|c|c|c|c|c|c|}
\hline University Category & $\begin{array}{c}\text { First-year } \\
\text { Student }\end{array}$ & Peer counselors & Student leaders & $\begin{array}{c}\text { Student } \\
\text { Counsellors }\end{array}$ & Deans of students \\
\hline Old Urban & 111 & 4 & 3 & 1 & 1 \\
\hline Old Rural & 86 & 4 & 3 & 3 & 3 \\
\hline New Urban & 103 & 12 & 9 & 4 & 4 \\
\hline New Rural & 98 & 16 & $\mathbf{2 7}$ & $\mathbf{9}$ \\
\hline Total & $\mathbf{3 9 8}$ & $\mathbf{3 6}$ & & & \\
\hline
\end{tabular}

Table 3:- Distribution of the sample for the study

Source: Researcher (2020)

Table 3 shows the distribution of first-year student samples, peer counselors, student leaders, student counselors, and deans of students in the four categories of universities. 


\section{RESULTS AND DISCUSSION}

Analysis of variance of academic adjustment among categories of universities

Analysis of variance was computed to determine any significant difference in at least two categories of universities in terms of academic adjustment.

\begin{tabular}{|c|c|c|c|c|c|}
\hline & Sum of Squares & Df & Mean Square & F & Sig. \\
\hline Between Groups & 11.744 & 3 & 3.915 & .616 & \\
\hline Within Groups & 417.914 & 386 & 1.083 & & \\
\hline Total & 429.658 & 389 & & \\
\hline
\end{tabular}

Table 4:- Analysis of variance of academic adjustment among categories of universities

One-way ANOVA results (Table 4) revealed an $\mathrm{F}(3,386)=3.616$, p-value $=.013<0.05$, indicating that at least one pair of the categories was statistically different.

A post-doc analysis was done to ascertain specific areas of difference among the university categories (Table 5)

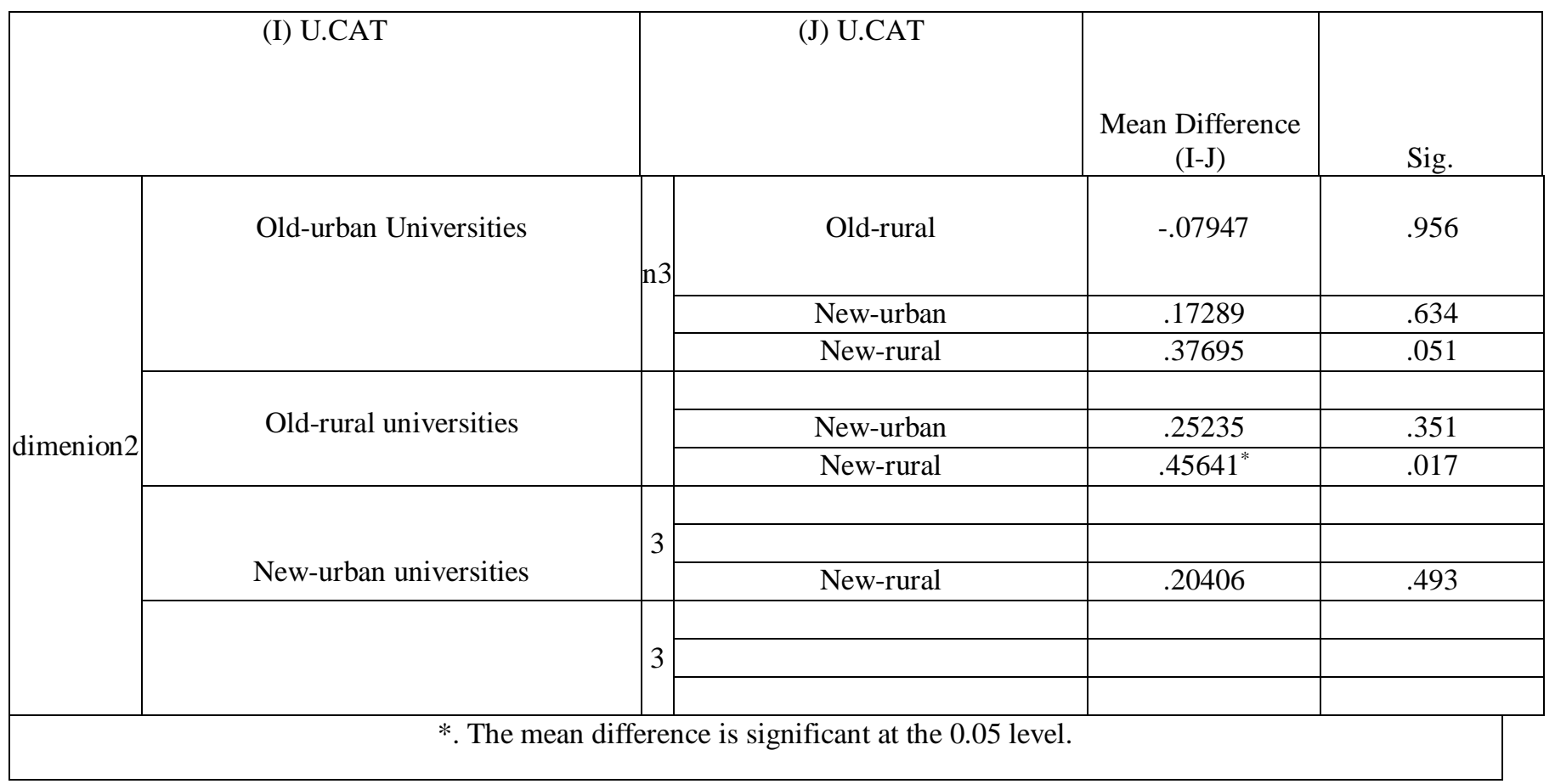

Table 5:- Post-hoc analysis of academic adjustment

A post-doc analysis (Table 5) show that Old-rural University and New-rural University were the only ones with statistically significant differences (mean difference $=.45641^{*}, \mathrm{p}$-value $=0.017<0.05$ ). Thus, the orientation programme assisted first-year students in old-rural universities academically than in new-rural universities. The differences observed were attributed to academic structures in old-rural universities that are well defined. The academic orientation of first-year students is conducted at the departmental level, and students issued with brochures spelling out the details of what students ought to know. On the other hand, in new-rural universities, academic structures are not as well defined. Therefore academic orientation for first-year students is done at the faculty/school level, and students are not issued with any reference material. Students at old-rural universities have a close encounter with the facilitators, receive detailed information, and refer to the brochure. Therefore, Students in old universities registered higher adjustment levels compared to their counterparts in new-rural University. 
Further, a detailed post-hoc analysis was done to determine how academic adjustment items compared in the different university categories. The results are in Tables $6,7,8$, and 9.

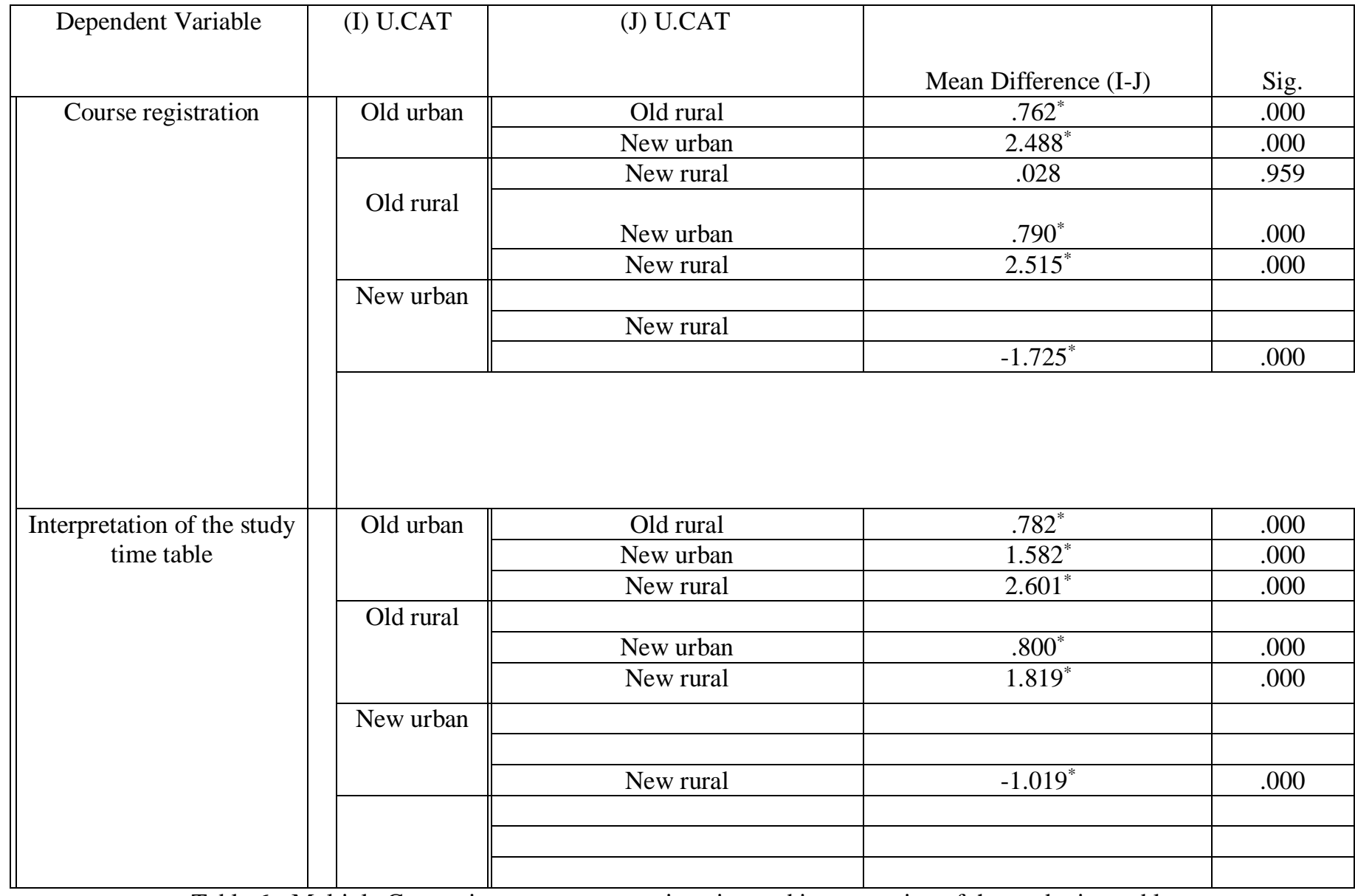

Table 6:- Multiple Comparisons on course registration and interpretation of the study time table

Table 6 Tukey HSD analysis shows no significant difference $($ sig=.959) in course registration adjustment between the old-urban universities and new- rural universities. However, there was a significant difference $(\mathrm{p}=.000)$ and better course registration adjustment in oldurban universities than old-rural universities (Mdf $=+$ $\left..762^{*}\right)$, and new-urban universities (Mdf $\left.=2.488^{*}\right)$. Equally, the influence was significant $(\mathrm{p}=.000)$ and higher at oldrural universities than new-urban universities $\left(\mathrm{Mdf}=+.790^{*}\right)$; and new-rural universities $\left(\mathrm{Mdf}=+2.515^{*}\right)$ On the other hand, the influence was significant $(\mathrm{p}=.000)$ but lower at the new-urban universities compared to newrural universities $\left(\mathrm{Mdf}=-1.725^{*}\right)$.

Table 6 shows that the influence of orientation on the interpretation of the study time table was significant $(\mathrm{p}=.000)$ and higher at old-urban universities than old-rural $\left(\mathrm{Mdf}=+.782^{*}\right)$, new-urban $\left(\mathrm{Mdf}=+1.582^{*}\right)$, and new-rural $\left(\mathrm{Mdf}=+2.601^{*}\right)$. Equally, the influence was significant $(\mathrm{p}=.000)$ and higher at old-rural universities than newurban universities $\left(\mathrm{Mdf}=+.800^{*}\right)$ and new-rural universities $\left(\mathrm{Mdf}=+1.819^{*}\right)$. However, the adjustment was significant $(\mathrm{p}=.000)$ but lower at new-urban than new-rural (Mdf=$\left.1.019^{*}\right)$ universities.
The study found out that the variation in adjustment levels shown in Table 5 was due to the qualifications of staff involved in guiding the students and the level where orientation for course registration is done. In old universities, it is done at the departmental level, and the facilitators are senior members of the department. In contrast, in new universities, it is done at the faculty level by even administrative staff. Further, in old universities, students are issued with brochures that offer further guidance. Therefore, students in old universities get clear and detailed information compared to their counterparts in new universities and, hence, higher adjustment.

Further, the study findings established that old universities have study timetable done and distributed to first-year students at the schools or departmental levels. Thus the timetable is lean and is easily understood by new students. In new universities, compared to old universities, the study timetable is combined, covering all faculties/schools in the majority of the cases. Hence, firstyears find it confusing and challenging to comprehend. However, the majority of new-rural universities offer fewer courses than most of the new-urban universities. Therefore, the study timetable is not as congested and confusing, and students can interpret it with relative ease. 
ISSN No:-2456-2165

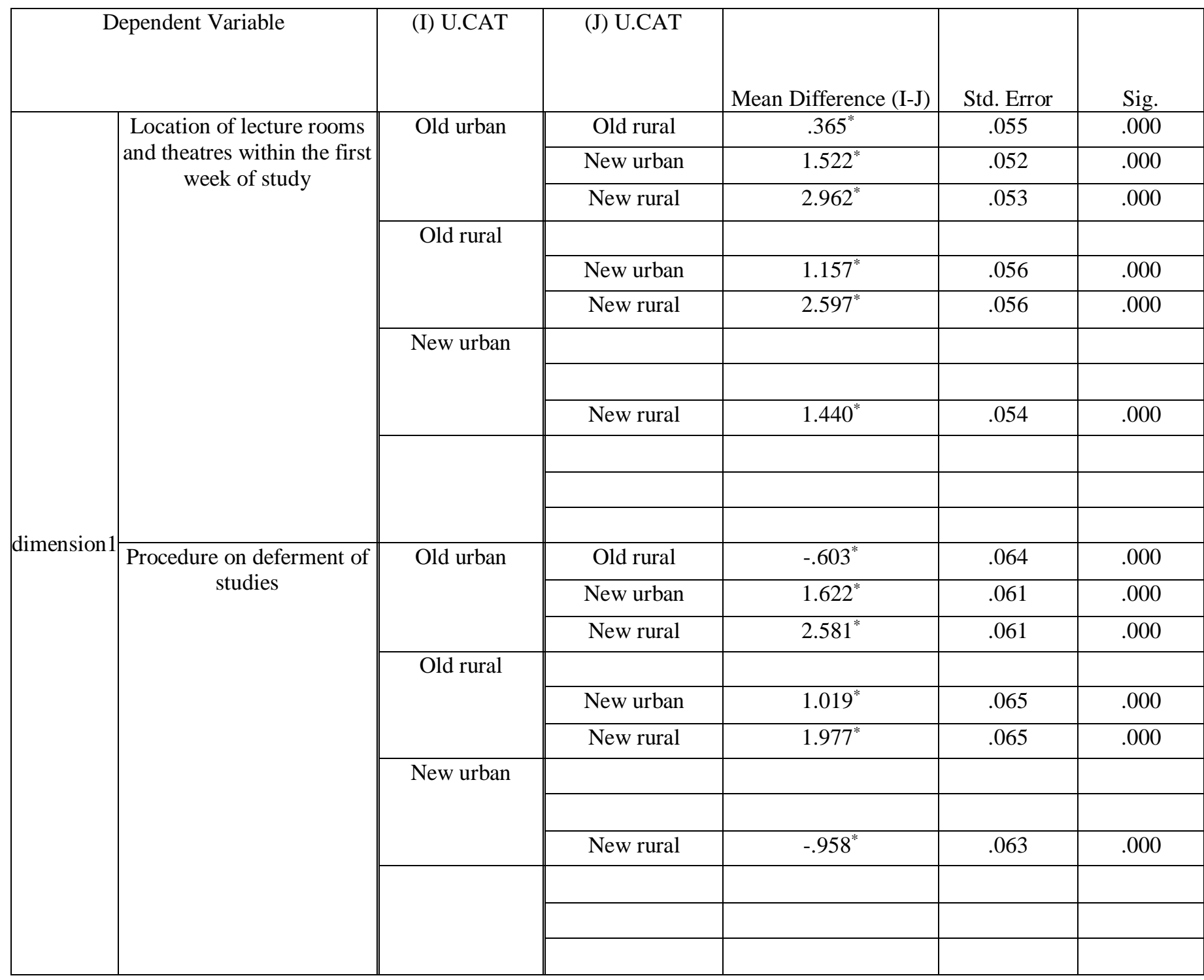

Table 7:- Multiple Comparisons on the influence of orientation on the location of lecture rooms and procedure of study deferment

Table 7 Tukey HSD analysis shows that the influence of orientation on the location of lecture rooms and theatres within the first week of study was significant $(\mathrm{p}=.000)$ and higher at old- urban universities than old-rural $(\mathrm{Mdf}=+.365)$, new-urban $\left(\mathrm{Mdf}=+1.522^{*}\right)$, and new-rural $\left(\mathrm{Mdf}=+2.962^{*}\right)$. Also, the influence was significant $(\mathrm{p}=.000)$ and higher at old-rural universities than newurban $\left(\mathrm{Mdf}=+1.157^{*}\right)$ and new rural $\left(\mathrm{Mdf}=+2.597^{*}\right)$ universities. Nevertheless, the influence was significant $(\mathrm{p}=.000)$ and higher $\left(\mathrm{Mdf}=+1.440^{*}\right)$ at new-urban universities than new-rural universities.

Table 7 shows that the influence of orientation programme on the procedure of deferment of studies was significant $(\mathrm{p}=.000)$, but lower at old-urban universities than old-rural $\left(\mathrm{Mdf}=-.603^{*}\right)$, while it was higher at oldurban universities than at new-urban universities $\left(\mathrm{Mdf}=+1.622^{*}\right)$, and new-rural universities $\left(\mathrm{Mdf}=+2.581^{*}\right)$. Similarly, the influence was significant $(\mathrm{p}=.000)$, and higher at old-rural universities than new-urban universities
$\left(\mathrm{Mdf}=+1.019^{*}\right)$, and new-rural universities $\left(\mathrm{Mdf}=+1.977^{*}\right)$. However, the influence was significant $(\mathrm{p}=.000)$ but lower in new-urban universities than new-rural universities $\left(\mathrm{Mdf}=-.958^{*}\right)$.

The differences observed in Table 6 were attributed to the reality that in old universities, many of the schools/faculties have the lecture rooms located in the same building, making it easier for new students to find their bearing. On the other hand, in the majority of the new universities, the lecture rooms are located in different buildings that are distances apart. Therefore students take time to trace and master the specific lecture rooms for different units. The study findings also revealed that the differences were due to the clarity and length of the deferment procedure. Universities that have a transparent and shorter process of deferment of studies registered higher adjustments than those with lengthy procedures of deferring studies. 


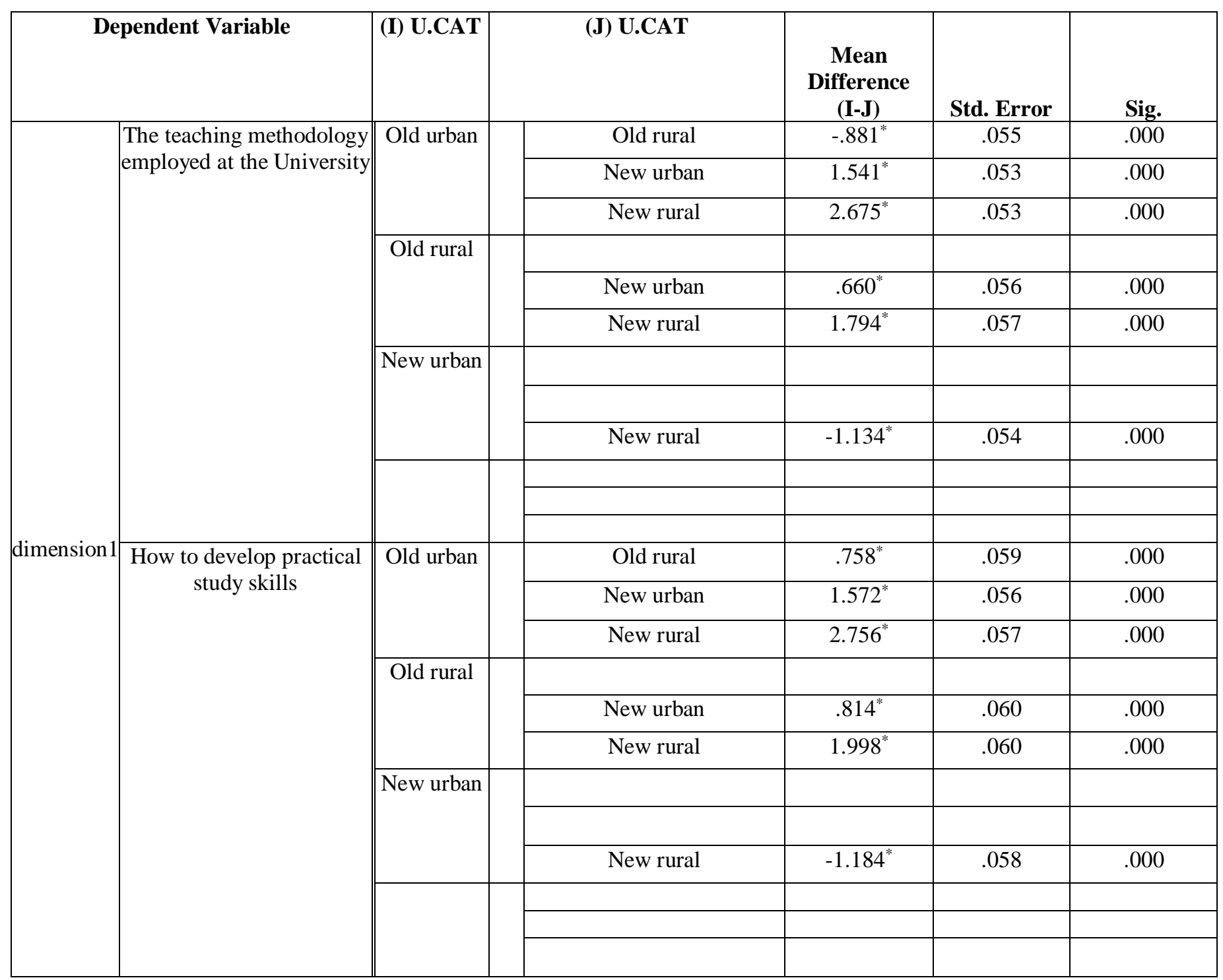

Table 8:- Multiple Comparisons on teaching methodology and development of compelling study

Table 8 shows that the influence of orientation programme on teaching methodology, was significant $(\mathrm{p}=.000)$, but lower at old-urban universities than old-rural universities $\left(\mathrm{Mdf}=-.881^{*}\right)$, however, it was higher at oldurban universities than new-urban universities $\left(\mathrm{Mdf}=+1.541^{*}\right)$, and new-rural universities $\left(\mathrm{Mdf}=+2.675^{*}\right)$. Also, the influence was significant $(\mathrm{p}=.000)$, and higher at old-rural universities than new-urban universities $\left(\mathrm{Mdf}=+660^{*}\right)$ and new-rural universities $\left(\mathrm{Mdf}=+1.794^{*}\right)$. But, the influence was significant $(\mathrm{p}=.000)$, and lower at new-urban universities than new-rural universities (Mdf=$\left.1.134^{*}\right)$.

Table 8 reveals that the influence of the orientation programme on how to develop effective study skills was significant $(\mathrm{p}=.000)$ and higher at old-urban universities than old-rural universities $\left(\mathrm{Mdf}=+.758^{*}\right)$, new-urban universities $\left(\mathrm{Mdf}=+1.572^{*}\right)$, and new-rural universities $\left(\mathrm{Mdf}=+2.756^{*}\right)$ respectively. Equally, the influence was significant $(\mathrm{p}=.000)$ and higher at old-rural universities than new-urban universities $\left(\mathrm{Mdf}=+.814^{*}\right)$ and new rural universities $\left(\mathrm{Mdf}=+1.998^{*}\right)$. Nevertheless, the influence was significant $(\mathrm{p}=.000)$ but lower at new-urban universities than new-rural universities $\left(\mathrm{Mdf}=-1.184^{*}\right)$.

The differences observed in Table 7 were explained by the study's findings that rural universities pay more attention to guiding students on certain aspects to retain as many students admitted as possible. Observation indicates that some of the students admitted to rural universities are not as settled as those admitted to urban universities. Also, old universities conduct academic orientation at departmental or faculty/school level. Also, findings that new-rural universities attained higher adjustment than newurban universities in developing practical study skills were attributed to the fact that various universities have different experts in given areas. They, as a result of preference, lay greater emphasis in given aspects compared to others. 


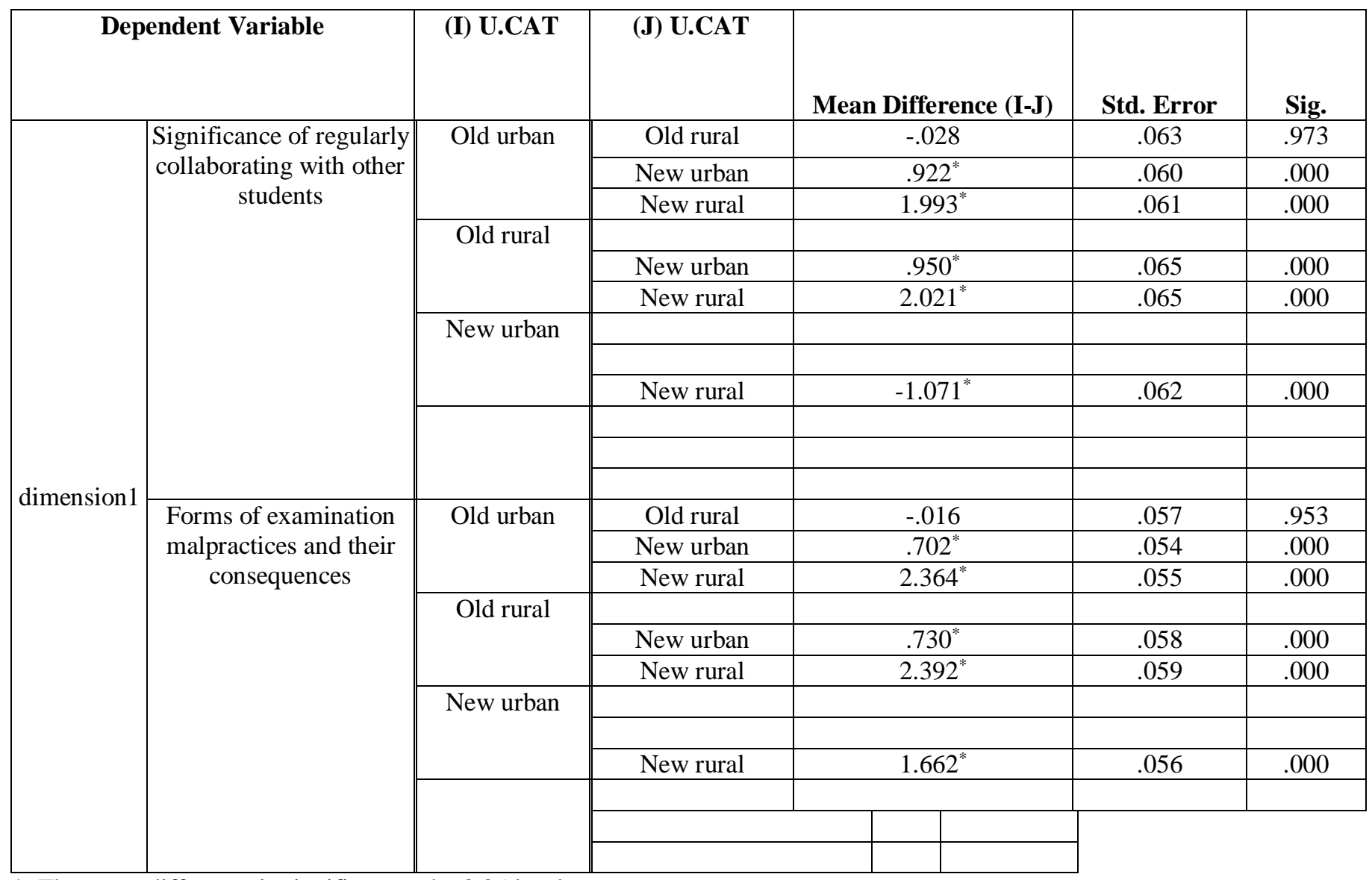

*. The mean difference is significant at the 0.05 level.

Table 9:- Multiple comparisons on the significance of regularly collaborating and forms of examination malpractices

Table 9 Tukey HSD analysis shows that the influence of the orientation programme on the significance of regularly collaborating with other students was not significant $\left(\mathrm{p}=.973^{*}\right)$ between old-urban universities and old-rural universities. The influence was significant $(\mathrm{p}=.000)$ and higher at old-urban universities than newurban universities $\left(\mathrm{Mdf}=+.922^{*}\right)$, and new-rural universities (Mdf $=+1.993)$. Equally, it was significant $(\mathrm{p}=.000)$ and higher at old-rural universities than new-urban universities $\left(\mathrm{Mdf}=+.950^{*}\right)$ and new-rural universities $\left(\mathrm{Mdf}=+2.021^{*}\right)$. However, the influence was significant $(\mathrm{p}=.000)$ but lower at new-urban universities than new-rural universities $\left(\mathrm{Mdf}=-1.071^{*}\right)$.

Table 9 further shows that the influence of the orientation programme on forms of examination malpractices and their consequences between old-urban universities and old-rural universities was not significant $\left(\mathrm{p}=.953^{*}\right)$. However, the influence was significant at $(\mathrm{p}=.000)$ and higher at old-urban universities than newurban universities $\left(\mathrm{Mdf}=+.702^{*}\right)$, and new-rural universities $\left(\mathrm{Mdf}=+2.364^{*}\right)$. Likewise, the influence was significant $(\mathrm{p}=.000)$ and higher at old-rural universities than newurban universities $\left(\mathrm{Mdf}=+.730^{*}\right)$, and new-rural universities $(\mathrm{Mdf}=+2.392)$. Similarly, the influence was significant $(\mathrm{p}=.000)$ and higher at new-urban universities than newrural universities $\left(\mathrm{Mdf}=+1.662^{*}\right)$.
Table 9 findings show that old universities spend relatively more time interacting closely with first-year students at a departmental level. Therefore, they give more guidance on the significance of regularly collaborating with other students and forms of examination malpractices, and their consequence registered higher adjustment. In new universities, students are addressed in big gatherings or at schools level within a limited amount of time, and hence the lower levels of adjustment attained. Moreover, the study established that orientation in different universities is carried out in different environments, by different people, with different experiences, modes of presentation, different areas of preference, and emphasis. Therefore, the results are also different.

The orientation of first years in the academic adjustment was higher in old-universities than newuniversities. Moreover, students in old-rural universities adjusted significantly better academically than students in new-rural universities. Detailed analyses reveal that the levels of adjustment on various academic items differed significantly among the different categories of public universities. The adjustment was highest at old-urban universities followed by old-rural universities, new-rural universities, and lowest at new-urban universities. It is in line with; interpretation of the study time table, location of lecture rooms, and theatres within the first week of study and on how to develop practical study skills. In procedure 
on deferment of studies and teaching methodology employed at the University, the adjustment was highest at old-rural universities followed by old-urban universities, new-rural universities, and lowest at new-urban universities.

Contrastingly, there was no difference in adjustment on the interpretation of course codes of the units of study, the significance of regularly collaborating with other students, and forms of examination malpractices and their consequences between old-urban universities and old-rural universities. However, new-rural universities realized higher adjustment level than new-urban universities in the interpretation of course codes of the units of study, and insignificance of regularly collaborating with other students. While in forms of examination malpractices and their consequences, the adjustment was higher at newurban universities compared to new-rural universities.

Orientation programme activities helped first-year students adjust academically. They were consistent with past research by Soria, Clark, and Koch (2013), where a first-year summer institute orientation programme facilitated the transition from high school to college in the academic domain. Bell et al. 's (2014) study established that students who participated in outdoor orientation programmes registered increased not only higher levels of learning but also a proper adjustment.

Also, Deil-Amen's (2011) study findings indicated that students' interactions with faculty are considered more crucial for social capital transmission than are their interactions with advisors or counselors. Further, Pascarella, Salisbury, and Blaich (2011) established that a sense of support by faculty could influence students' ability to adjust to College. Similarly, Barnett's (2011) study on the importance of faculty support found that support promoted academic adjustment in College. Besides, Komarraju and colleagues (2010) found that having offcampus contact with faculty, feeling respected by them, and perceiving them as approachable are all related to higher self-concept and academic adjustment.

This study also found out that first-year students complained that faculty members were not available to attend to their concerns. These findings are consistent with Sevinc and Gizir (2014) findings, whose study indicates that first-year students described their faculties as less caring, warm, and supportive and that both formal and informal relationships between students and faculty were relatively infrequent. Lack of faculty support can contribute to sense isolation, and may lead to adjustment challenges. These findings confirm and extend Klein's (2013) conclusion that students feel a greater sense of belonging when contact with faculty over academic matters cultivates a connection between the student and the faculty that can resemble elements of family and friend relationships. Moreover, faculty who take a proactive approach to help students navigate within the organization provide the needed information for students to overcome procedural obstacles, thereby enhancing their adjustment.
The findings are similar to Hassel and Ridout's (2018) study on an investigation of first-year students' and lecturers' expectations of university education, which indicated that 39percent of students struggled to keep up with the workload while over 30 percent encountered challenges in developing an independent learning style. Meuleamn, Garrett, Wrench, and King's (2015) study also indicates that students faced challenges such as not receiving enough assistance from tutors and lecturers as expected, increased responsibility for learning, high expectations, adjustment to different grading systems and general difficulty of assignments.

The findings of this study also revealed that students find it challenging to attend lectures due to Poor and congested learning infrastructure, forcing some students to attend lectures from the corridors. As a result, some decide not to attend at all. This finding concurs with similar findings by Kandinko and Mawer (2013), whose study shows that students found it challenging to adjust to larger lecture-type classes. In the same study, students demonstrated a liking for small tutorial-style classes that present more significant opportunities for face-to-face interactions with teaching staff. Similarly, Gudo and Olel (2011) found out that in many Kenyan Universities, students face old and congested lecture theatres. Such a lack of learning environment may lead to discouragement and dissatisfaction that may negatively impact students' academic adjustment and sequential progression.

Pre-university experiences of first-year students on matters academic markedly differ with the real experiences at the University. As a result, many students experienced academic struggles as they enter University (Hassel \&Ridout 2018) because pre-university educational experience does not adequately prepare them for study at the University (Bok, 2010).

Although overall, the study established that the orientation programme facilitated students' academic adjustment, the variables that scored highest Means are those that deal with more or less logistical issues. Coincidentally, these are the areas that studies have revealed pose real challenges to transitioning students. The implication is that in the designing and much emphasis should be laid on the areas that matter to attain a smooth and higher academic adjustment and academic success in the long run.

\section{CONCLUSION}

Students in old-rural universities adjusted significantly better academically than students in new-rural universities (mean difference $=.45641^{*}, \quad \mathrm{p}$-value $=0.017<0.05$ ). Detailed analyses revealed that the levels of adjustment on various academic sub-variables differed significantly among the different categories of public universities.

However, in procedure on deferment of studies, and teaching methodology employed at the University, adjustment was highest at old-rural universities followed by 
old-urban universities, new-rural universities, and lowest at new-urban universities. Contrastingly, there was no difference in adjustment on the interpretation of course codes of the units of study, the significance of regularly collaborating with other students, and forms of examination malpractices and their consequences between old-urban universities and old-rural universities. However, new-rural universities realized higher adjustment level compared to new-urban universities in the interpretation of course codes of the units of study, and insignificance of regularly collaborating with other students. Whereas, in forms of examination malpractices and their consequences, the adjustment was higher at new-urban universities compared to new-rural universities.

In old-rural universities, academic advising of firstyear students is conducted in smaller groups at faculty and departmental levels. Students are issued with brochures, thus promoting better interaction between students and faculty. Additionally, in some institutions, students have access to online materials that offer additional support. On the other hand, there appeared to be limited interaction between faculty and students in new universities because academic advising is done at the faculty level, limiting the amount of information, activities, or details available to the students. Moreover, students have limited time to go through orientation activities on academic advising, and the supplementing materials are few compared to their counterparts in old universities. Students at old-rural universities receive detailed and specific information and reference material and attained higher adjustment compared to their counterparts in new-rural universities.

Coincidentally, these are the areas that studies have revealed pose real academic challenges to transitioning students (Mudhovozi, 2012). The implication is that in the designing and execution of faculty and academic advising, much emphasis should be laid on the areas that matter to attain a smooth and higher level of academic adjustment and academic success in the long run.

\section{REFERENCES}

[1]. Abdullah, M. C., Elias, H., Mahyddin, R.,\&Uli, J. (2009). Adjustment amongst first-year students in a Malaysian University. European Journal of Social Sciences, 8(3), 496-505. Retrieved from http://www.eurojournals.com/ejss_8_3_13.pdf

[2]. Abdullah, C. H., Elias, H., Uli, J., \&Mahyuddin, R. (2010).Relationship between coping and university adjustment and academic achievement amongst firstyear undergraduates in a Malaysian public university. International Journal of Arts and Sciences, 3(11), 379 $-392$

[3]. Al-khatib, B. A., Awamleh, H. S., \&Samawi, F. S. (2012). Student's adjustment to college life at Albalqa Applied University.American International Journal of Contemporary Research, 2(11), 7 - 17.

[4]. Ameri, S., Fard, J., Ratna, B., Chinnam, R. B., \& Reddy, C. K. (2016). Survival analysis based framework for early prediction of student dropouts.
Journal of College Student Retention: Research, Theory \& Practice, 13(1) 903 - 912.

[5]. Briggs A.R.J., Clark, J.,\& Hall, I. (2012) Building bridges: understanding student transition to University, Quality in Higher Education, 18:1, 3-21, DOI:10.1080/13538322.2011.614468

[6]. Brinkworth, R., Mccann, B., Matthews, C., \&Nordstrom,"M. K. (2009). "First-Year Expectations and Experiences: Student and Teacher Perspectives." Higher Education 58 (2): 157-173.

[7]. Budgen, F., Main, J. S., Callcott, D., \&Hamlett, B. (2014). The first year at University: Giving Social Capital a Sporting Chance. Australian Journal of Teacher Education, 39(7), 157 - 172. Retrieved from http://ro.ecu.edu.au/ajte/vol39/1ss7/9

[8]. Burke, J., \& Larry, C. (2012).Educational research: quantitative, qualitative, and mixed research approaches $\left(4^{\text {th }}\right.$ ed.). SAGE Publications, Inc.

[9]. Carter, M. A., Pagliano, P., Francis, A., \& Thorne, M. (2017).Australian university students and mental health: viewpoints from the literature. International Journal of Innovation, Creativity, and Change, 3(3), www.ijicc.net

[10]. Clark, J. \& Hall, I., 2010, 'Exploring Transition: The experiences of students at Newcastle University in their first year,' Newcastle University, UK. Available online http://eprint.ncl.ac.uk/pub_details2.aspx?pub_id=1667 07 (accessed 21 March 2011).

[11]. Creswell, J. W. (2014). Research Design. Qualitative, Quantitative, and Mixed Methods Approach (4 ${ }^{\text {th }}$ Ed.). The University of Nebraska-Lincoln. SAGE Publications, Inc.

[12]. Crisp, G., Palmer, E., Turnbull, D., Netelbeck T., \&Ward, L. (2009). First-year student expectations: results from a university-wide student survey. J. Univ. Teach. Learn. Pract. 6:2009 Available online at http://ro.uow.edu.au/jutlp/vol6/iss1/3

[13]. Emmanuel., O.U.,\&Ovie, T. P. T. I. B. (2015). Adjustment problem of national diploma student in the burst environment- a case study of the delta state school of marine technology, burutu delta state.International Journal of Multidisciplinary and Current Research, 3(6) 489 - 494.

[14]. Gall, M. D., Gall, J. P., \& Borg, W. R. (2007). Educational research: An introduction (8th ed.). Boston: Pearson

[15]. Gudo, C. O., \&Olel, M. A. (2011). Students' Admission Policies for Quality Assurance: Towards Quality Education in Kenyan Universities. International Journal of Business and Social Sciences, 2(8), $177-183$.

[16]. Herbling, D. (2013, May 21). The accommodation crisis hits the University of Nairobi.

[17]. Business Daily.Retrieved from https://www.businessdailyafrica.com/corporate/539 550-1859122-14uyrl9/index.html

[18]. Huie, F. C., Winsler, A., \&Kitsantas, A. (2014). Employment and first-year college achievement: The role of self-regulation and motivation. Journal of Education and Work, 27, 110-135. doi:10.1080/13639 
[19]. Kamunyu, N.R., Ndungo, C., \&Wango, G. (2016). Reasons Why University Students do not Seek Counselling Services in Kenya. Journal of Education and Practice, 7(15), 142 -144.

[20]. Kandinko C. B.,\&Mawer, M. (2013).Student Expectations and Perceptions of Higher Education.A study of UK higher education Commissioned by the Quality Assurance Agency. Available online at https://www.kcl.ac.uk/study/learningteaching/kli/Peop le/Research/DL/QAAReport.pdf

[21]. Kenya Universities and Colleges Central Placement Services (KUCCPS). (2018). (https://www.advanceafrica.com/top-2018kcse-students-pick-medicine-andengineering.html

[22]. Kitsantas, A., \& Zimmerman, B. J. (2009). College students' homework and academic achievement: The mediating role of self-regulatory beliefs. Metacognition Learning, 4, 97-110. doi:10.1007/s11409-008-9028-y

[23]. Leese, M. (2010)."Bridging the Gap: Supporting Student Transitions into Higher Education." Journal of Further and Higher Education 34 (2): 239-251.

[24]. Meuleman, A-M, Garrett, R., Wrench, A. \& King, S.(2015). "Some people Might Say I" $m$ Thriving but?...: Non-Traditional Students" Experiences of University." International Journal of Inclusive Education, 19(5), 503-517.

[25]. Mohamed, N. (2012). Adjustment to University: predictors, outcomes, and trajectories. Retrieved January, 2015 from tp://clok.uclan.ac.uk/6556/1/mohamenadiah final Edith

[26]. Mudhovozi, P. (2012). Social and academic adjustment of first-year university students, Journal of Social Sciences, 33(2), 251 - 259.

[27]. Mugenda, O. M. \& Mugenda, A. G. (2013).Research Methods: Qualitative and Quantitative Approaches. Nairobi: ACTS Press.

[28]. Murtagh, L. (2010). They give us homework! Transition to higher education: the case of initial teacher training. Joining further higher education, 34(6),405-418. 10.1080/0309877X.2010.484057.

[29]. Otieno, R. (2013, May 20). Understanding the reasons for 'killing student aspirations.' The Standard (p.9). Nairobi, Kenya: The Standard Media Group.

[30]. Rice, K. G. (2009). Separation-individuation and adjustment to College, A longitudinal study.Journal of Counselling Psychology, 39(2), 203-213. Retrieved from http://dx.doi.org/10.1037/0022-0167.39.2.203

[31]. Salami, S. O. (2011).Psychosocial predictors of adjustment among first-year College of Education students.US-China Education review, 8(2), 239 - 248.

[32]. Sommer, M. M. (2013).Psychosocial factors predicting the adjustment and academic performance of university students. Retrieved from http://uir.unisa.ac.za/bitstream/handle/10500/13283/th esis_sommer_mm.pdf

[33]. Trochim, W. M. K. (2020). Research methods base. Retrieved from https://conjointly.com/kb/.
[34]. Wasylkiw, L. (2016). Students' perspectives on pathways to university readiness and adjustment Journal of Education and Training Studies, 4(3), 28 39.

[35]. Williamson, M., Laybourn, P., Deane J., Tait, H. (2011).Closing the gap: An exploration of first-year students' expectations and experiences of learning.Psychology of Learning and. Teaching, 10, 146-157. 10.2304/plat.2011.10.2.146 